\title{
The effect of Pilates practice on balance in elderly:
} a systematic review

\author{
Efeito da prática do Pilates sobre o equilíbrio de idosos: uma revisão sistemática
}

\begin{tabular}{l} 
AUTHOR'S \\
\hline Araceli Goedert $^{1}$ (D) \\
Karini Borges dos Santos $^{1}$ (D) \\
Paulo Cesar Barauce Bento ${ }^{1}$ (D) \\
André Luiz Felix Rodacki ${ }^{1}$ (D) \\
1 Universidade Federal do Paraná, Setor de Ciências \\
Biológicas. Curitiba, Paraná, Brasil. \\
CORRESPONDING \\
\hline Karini Borges dos Santos \\
kariniborges2@gmail.com \\
Rua Coração de Maria, 92, \\
Jardim Botânico, Curitiba, Paraná. Brasil. \\
CEP: 80215-370 \\
DOI
\end{tabular}

10.12820/rbafs.23e0019

\section{c) $(\$)$ \\ BY NC ND}

Copyright: This is an open-access article distributed under the terms of the Creative Commons Attribution License ${ }^{\circledR}$, which permits unrestricted use, distribution, and reproduction in any medium, provided that the original author and source are credited.

\begin{abstract}
The aging is accompanied by a gradual decline in balance and increases risk of falls. Pilates has been used for balance training. The purpose of this research was to systematize studies regarding the effects of Pilates exercise interventions on static and dynamic balance of elderly people. A survey was conducted in three indexed databases: Medline/Pubmed, Scopus and Science Direct, using the descriptors "balance" or "equilibrium" with the term "Pilates". Fifteen articles were selected and used in this systematic review. Based on the results, we observed that the practice of Pilates with a minimum frequency of two sessions per week for an hour lasting for a period of at least five weeks or three times per week for 12 sessions or more showed improvement on static and dynamic balance of elderly.
\end{abstract}

Keywords: Physical activity; Balance; Elderly; Exercise movement techniques.

RESUMO

O envelhecimento é acompanhado por um declinio gradual no equilibrio e aumento do risco de quedas. Pilates tem sido utilizado para o treinamento do equilibrio. O objetivo desta pesquisa foi sistematizar estudos que evidenciem os efeitos da intervenção com exercícios de Pilates sobre o equilíbrio estático e dinâmico de idosos. Uma pesquisa foi realizada em três bases de dados indexadas: Medline/Pubmed; Scopus e Science Direct, a partir da associação dos descritores "balance" ou "equilibrium" com o termo "Pilates". Quinze artigos selecionados e analisados foram utilizados para compor esta revisão sistemática. A partir dos resultados foi possivel verificar que a prática de Pilates realizada com frequência minima de duas sessões semanais, por uma hora por dia, em periodo igual ou superior a cinco semanas resultou em melhorias no equilíbrio estático e dinâmico de idosos.

Palavras-chave: Atividade física; Equilibrio postural; Idosos; Técnicas de exercício e de movimento.

\section{Introduction}

Increased life expectancy has generated growing interest in understanding health problems related to aging. It has been well established that aging is accompanied by a gradual decline in balance due changes in proprioceptive system $^{1}$, which can increase risk of falls. Falls in elderly remain a major source of morbidity, mortality, reduced functionality and independence ${ }^{2}$.

Balance is defined as a person's ability to control their body position within the limits of the base of support ${ }^{3}$. Balance can be categorized in Static balance (quiet erect standing) and Dynamic balance (the capacity to maintain or regain a stable position of the body during movements or in response to a perturbation $)^{4}$. Maintaining balance is crucial for the successful performance of most movements practiced in daily life or movements involv- ing high complexity and requiring self-proper body control ${ }^{5,6}$. Postural control is resultant of the synergy of small muscle contractions, which maintain the center of gravity within the limits of stability and orientation of the body in order to adapt to gestures and techniques according to the demand of the activity ${ }^{7,8}$. Postural control depends on the interaction of the sensory system (visual, vestibular and somatosensory) with the central nervous system and with the neuromuscular system. The central nervous system receives sensory information about the body position and responds by activating a specific musculature ${ }^{9}$.

The deep muscles of the trunk or core muscles have been identified as great aids to maintain balance ${ }^{10-12}$. Core consists of 29 muscles separated into two systems: global, which are superficial muscles that perform movements dynamically; and local, which are the deep muscles (in- 
cluding multifidus and transversus abdominis) responsible for stabilizing the trunk during the performance of activities. The better the activation of core muscles, the better the individual's ability to maintain balance ${ }^{13,14}$.

The practice of Pilates has been widely used to activate the muscles of the core. The method focuses on toning the deep core stabilizer muscles using control and conscious movements that allows the practitioner to improve fitness, muscle tone, posture, flexibility and balance ${ }^{11,12,15}$. Exercises can be performed on mat using the body weight, or with specific apparatus, such as the Reformer, Cadillac, Chair and Barrel, which were developed by the creator, Joseph Pilates (1880-1967). Other accessories as elastics, ball and rollers are also used during mat or apparatus classes to enable different kinds of exercises in order to improve strength, stretching and postural realignment ${ }^{11,16}$.

Experiment results have consistently demonstrated that Pilates has a positive effect on healthy subjects' balance. Indeed, Cruz-Ferreira ${ }^{17}$ conducted a systematic review and found evidences to support the use of Pilates to improve dynamic balance. However, there is some contradiction about the intervention methods, the frequency, time and the methods of evaluating balance and lack of consistent information regarding Pilates prescription for elderly people, who can be benefit with balance improvements and diminish risk of falls. In fact, it has not been established yet how much and what types of range of motion exercises are the most effective for elderly people ${ }^{18}$. Thus, this literature review aims to systematize studies focusing on the effects of an intervention with Pilates exercises on static and dynamic balance of elderly people.

\section{Methods}

Articles were selected on April 2017, by searching three indexed databases: Medline/PubMed; Scopus and Science Direct with the key words "balance" or "equilibrium" and the term "Pilates", which although it is not a health science descriptor, is fundamental to the development of this study.

A set of criteria were selected to compose the review and included: original articles; published in peer-reviewed journal; dated between 2006 and March 2017; written in English; conducted as randomized controlled trial, quasi-experimental studies and cross over method; evaluated the effect on subjects' balance; and studied healthy individuals with an average equal to or greater than 65 years.

The research initially generated a total of 762 articles. Of these, 488 studies were within the period of interest
(2006 - March 2017). After checking for repeated studies and verifying the terms in the title and abstract, 59 eligible articles were further screened. Two review authors independently applied inclusion criteria for the studies after reading abstracts and selecting potential studies. The assessors critically analyzed and discussed the selection of article and disagreements were resolved with a third reviewer when needed.

The articles were primarily selected by analysis according to the abstract, then by reading the full article, focusing on criteria and objectives of the study. At the end of the evaluation, fifteen relevant articles were included in this systematic review. The following data were extracted independently by two reviewers: author, years of publication, subjects, study design, Pilates method of intervention, balance variables studied and key results.

Methodology quality assessment was evaluated according to a protocol developed for the present study based on Bento et al. ${ }^{2}$. The 11 criteria judged important for this review were as follows: control group; random allocation of the subjects; initial similarity between groups; blind evaluation; intervention with Pilates method; supervised program; minimal frequency of training of twice a week; minimal duration of the program of eight weeks; static balance evaluation, dynamic balance evaluation; reliable instruments for assessment. Higher scores denoted better article quality.

Data were systematized by the comparison established between Pilates intervention and control group (inactive) or initial condition and post-intervention condition for studies with a single group. The results of the static and dynamic balance were used to report the differences. Strength of scientific evidence was measured by "best evidence synthesis", which determines strength by the number and quality of studies and consistency of results ${ }^{17}$.

\section{Results}

Flowchart of the article selection process is showed in Figure 1. Fifteen articles were considered relevant and were used in this systematic review. All of the selected studies conducted Pilates intervention with a minimum of 40 minutes sessions and evaluated the effects of this exercise on balance of elderly people. The average age of the participants was $70.35 \pm 2.85$ years. Although this is quite high, participants were in general healthy and physically independent.

Score for methodological quality assessment protocol ranged from 5 to 10 (mean 8), indicating moderate quality of studies. The quality criteria satisfied by all researches 
were related to "supervised program" and "reliable instruments for assessment". While the criteria least checked corresponded to "similarity between groups" ( 2 articles) and "blind evaluation" ( 6 articles). Score for methodological quality assessment protocol is presented in Table 1 .

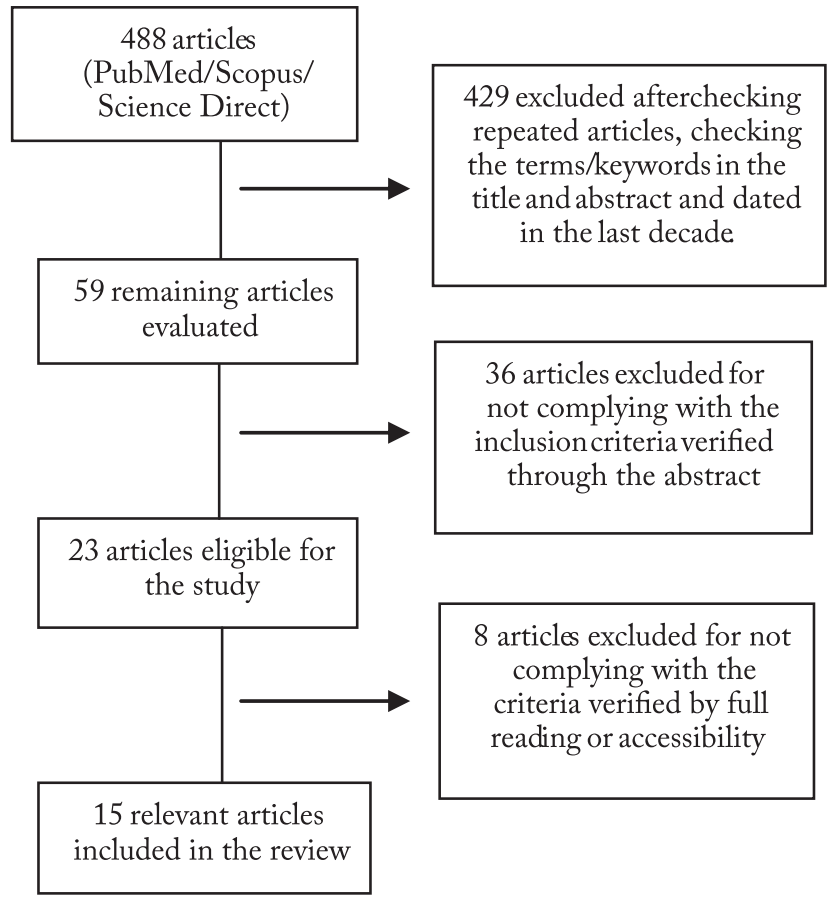

Figure 1 - Article selection process.

Regarding the methodological procedures, ten articles $(66.7 \%)$ conducted a randomized controlled study $^{19-29}$, while four articles ${ }^{30-33}(26.7 \%)$ conducted a quasi-experimental study evaluating the data from the same population before and after the intervention. Only one study ${ }^{34}(6.7 \%)$ used a cross over method.

Moderate evidence was found for improving static and dynamic balance by "best evidence synthesis". Four articles evaluated only static balance ${ }^{19,20,25,32}$, while three evaluate dynamic balance ${ }^{22,31,33}$ and eight both conditions ${ }^{21,23,24,27-29,30,34}$. Pilates exercise demonstrated ability to improve static and dynamic balance in almost all studies. Pilates methods, frequency, variables and results can be observed in Tables 2 and 3 .

\section{Discussion}

This review was conduct in order to systematize studies focusing on the effects of intervention with Pilates exercises on static and dynamic balance of elderly people. Fifteen select articles showed moderate to good methodological quality and evidence to support that exercise with apparatus or a combination of exercise on mat and with apparatus can improve both static and dynamic balance after an intervention period of twice per week or more. Mat Pilates exercises showed improvement when practiced with a minimum frequency of three times per week.

Although Newell et al. ${ }^{32}$ Pata et al..$^{33}$ and Donath et al. ${ }^{23}$ did not show significant results with mat and/or apparatus exercises once or twice per week, the results portray a positive trend in relation to balance. Kaesler et al. ${ }^{30}$, Siqueira et al. ${ }^{20}$, Barker et al. ${ }^{22}$, Josephs et al..$^{28}$ and Sofianidis et al. ${ }^{29}$ observed that Pilates practiced twice

Table 1 - Protocol to assessment methodology quality.

\begin{tabular}{|c|c|c|c|c|c|c|c|c|c|c|c|c|}
\hline & 1 & 2 & 3 & 4 & 5 & 6 & 7 & 8 & 9 & 10 & 11 & Total \\
\hline Barker et al..$^{22}$ & 1 & 1 & - & 1 & - & 1 & 1 & 1 & - & 1 & 1 & 8 \\
\hline Bird et al. ${ }^{34}$ & 1 & 1 & 1 & 1 & 1 & 1 & 1 & - & 1 & 1 & 1 & 10 \\
\hline Siqueira et al..$^{20}$ & 1 & 1 & - & - & 1 & 1 & 1 & 1 & 1 & - & 1 & 8 \\
\hline Donath et al..$^{23}$ & 1 & 1 & - & - & 1 & 1 & 1 & 1 & 1 & 1 & 1 & 9 \\
\hline Gabizon et al. ${ }^{24}$ & 1 & 1 & - & 1 & 1 & 1 & 1 & 1 & 1 & 1 & 1 & 10 \\
\hline Hyun et $\mathrm{al}^{21}$ & - & - & - & - & 1 & 1 & 1 & 1 & 1 & 1 & 1 & 7 \\
\hline Irez et al. ${ }^{19}$ & 1 & 1 & - & - & - & 1 & 1 & 1 & - & 1 & 1 & 7 \\
\hline Josephs et al. ${ }^{28}$ & - & 1 & - & 1 & - & 1 & 1 & 1 & 1 & 1 & 1 & 8 \\
\hline Kaesler et al. ${ }^{30}$ & - & - & - & - & 1 & 1 & 1 & 1 & 1 & 1 & 1 & 7 \\
\hline Markovic et al. ${ }^{25}$ & - & 1 & - & 1 & 1 & 1 & 1 & 1 & 1 & - & 1 & 8 \\
\hline Mesquita et al. ${ }^{27}$ & 1 & 1 & 1 & 1 & 1 & 1 & 1 & - & 1 & 1 & 1 & 10 \\
\hline Mokhtari et al. ${ }^{31}$ & 1 & 1 & - & - & - & 1 & 1 & 1 & - & 1 & 1 & 7 \\
\hline Newel et al..$^{32}$ & - & - & - & - & 1 & 1 & - & 1 & 1 & - & 1 & 5 \\
\hline Pata et al. ${ }^{33}$ & - & - & - & - & - & 1 & 1 & 1 & - & 1 & 1 & 5 \\
\hline Sofianidis et al. ${ }^{29}$ & 1 & 1 & - & - & - & 1 & 1 & 1 & 1 & 1 & 1 & 8 \\
\hline
\end{tabular}

1 = Control Group; 2 = Random allocation of the subjects; 3 = Initial Similarity between groups; $4=$ Blind evaluation; $5=$ Intervention with Pilates method only; 6 = Supervised program; 7 = Minimal frequency of training of twice a week; $8=$ Minimal duration of the program of eight weeks; 9 = Static balance evaluation; 10 = Dynamic balance evaluation; 11 = Reliable instruments for assessment. 
Table 2 - Methodological description of included articles.

\begin{tabular}{|c|c|c|c|c|}
\hline Study & Subjects $(\mathrm{n})$ & $\begin{array}{l}\text { Mean Age } \pm \text { SD } \\
\text { ears) }\end{array}$ & Study design & Method/ Frequency \\
\hline Barker et al. ${ }^{22}$ & $\begin{array}{l}\mathrm{PG}=22 \\
\mathrm{CG}=31\end{array}$ & $\begin{array}{l}53 \\
69.25 \pm 6.74 \\
69.41 \pm 5.76\end{array}$ & $\begin{array}{l}\text { follow-up/ randomized } \\
\text { controlled trial }\end{array}$ & $\begin{array}{l}\mathrm{PG}=2 \mathrm{x} \text { /week during } 12 \text { weeks -- reformer, trapeze, Wunda chair, } \\
\text { chi ball, elastic band and foam roller and } 20 \text {-minute home exercise } \\
\text { program daily } \\
\text { CG }=20 \text {-minute home exercise program daily }\end{array}$ \\
\hline Bird et al. ${ }^{34}$ & \multicolumn{2}{|c|}{$\begin{array}{l}\mathrm{PG}=13 \\
\mathrm{CG}=12\end{array}$} & cross over & $\begin{array}{c}\mathrm{PG}=2 \mathrm{x} / \text { week during } 5 \text { weeks }-- \text { apparatus and on mat } \\
\mathrm{CG}=\text { maintained normal physical activity }\end{array}$ \\
\hline Siqueira et al. ${ }^{20}$ & \multicolumn{2}{|c|}{$\begin{array}{rl}\mathrm{n}=52 & 66 \pm 4 \\
\mathrm{PG} & =27 \\
\mathrm{CG} & =25\end{array}$} & $\begin{array}{l}\text { randomized controlled } \\
\text { study }\end{array}$ & $\begin{array}{c}\mathrm{PG}=2 \mathrm{x} / \text { week during } 8 \text { weeks -- apparatus } \\
\text { CG: no intervention }\end{array}$ \\
\hline Donath et al. ${ }^{23}$ & $\begin{array}{l}\mathrm{PG}=17 \\
\mathrm{CG}=31 \\
\mathrm{BAL}=16\end{array}$ & $\begin{array}{l}=64 \\
\qquad \begin{array}{r}70.8 \pm 6.5 \\
69.2 \pm 6.1 \\
69.1 \pm 5.8\end{array}\end{array}$ & $\begin{array}{l}\text { randomized controlled } \\
\text { trial }\end{array}$ & $\begin{array}{c}\mathrm{PG}=2 \mathrm{x} / \text { week during } 8 \text { weeks }- \text { on mat } \\
\mathrm{CG}=\text { asked to regular daily activity schemes. } \\
\mathrm{BAL}=\text { traditional balance training } 2 \mathrm{x} / \text { week during } 8 \text { weeks }\end{array}$ \\
\hline Gabizon et al. ${ }^{24}$ & $\begin{array}{l}\mathrm{PG}=17 \\
\mathrm{CG}=31\end{array}$ & $\begin{array}{l}=64 \\
\quad 70.3 \pm 3.8 \\
71.2 \pm 4.6\end{array}$ & $\begin{array}{l}\text { randomized controlled } \\
\text { trial }\end{array}$ & $\begin{array}{c}\text { PG = 3x /week during } 12 \text { weeks. Mat, Thera-Band; elastic resistance } \\
\text { bands and Swiss balls } \\
\mathrm{CG}=\text { not receive any intervention }\end{array}$ \\
\hline Hyun et al. ${ }^{21}$ & $\begin{array}{l}\mathrm{PG}=20 \\
\mathrm{CG}=20\end{array}$ & $\begin{array}{l}=40 \\
\quad \begin{array}{l}70.0 \pm 2.2 \\
69.3 \pm 2.6\end{array}\end{array}$ & $\begin{array}{l}\text { randomized controlled } \\
\text { study }\end{array}$ & $\begin{array}{c}\mathrm{PG}=3 \mathrm{x} / \text { week during } 12 \text { weeks --on mat } \\
\mathrm{CG}=3 \mathrm{x} / \text { week during } 12 \text { weeks }- \text { on unstable support surface exercise } \\
\text { (Standing on aero step) }\end{array}$ \\
\hline Irez et al. ${ }^{19}$ & $\begin{array}{l}\mathrm{PG}=30 \\
\mathrm{CG}=30\end{array}$ & $\begin{array}{l}=60 \\
\quad \begin{aligned} 72.8 & \pm 6.7 \\
78.0 & \pm 5.7\end{aligned}\end{array}$ & $\begin{array}{l}\text { randomized controlled } \\
\text { study }\end{array}$ & $\begin{array}{c}\mathrm{PG}=3 \mathrm{x} / \text { week during } 12 \text { weeks -- on mat, with elastic and Swiss ball } \\
\mathrm{CG}=\text { no intervention }\end{array}$ \\
\hline Josephs et al. ${ }^{28}$ & $\begin{array}{l}\mathrm{PG}=13 \\
\mathrm{TG}=11\end{array}$ & $\begin{aligned} & 24 \\
& 75.6 \pm 6.72 \\
& 74.5 \pm 6.79\end{aligned}$ & $\begin{array}{l}\text { randomized controlled } \\
\text { trial }\end{array}$ & $\begin{array}{l}\mathrm{PG}=2 \mathrm{x} / \text { week during } 12 \text { weeks - with reformer, Cadillac and Chair } \\
\text { apparatus and } 15-20 \mathrm{~min} \text { home exercise program on non-program day } \\
\mathrm{TG}=2 \mathrm{x} / \text { week during } 12 \text { weeks traditional strength and balance } \\
\text { exercises and } 15-20 \text { min home exercise program on non-program day }\end{array}$ \\
\hline Kaesler et al. ${ }^{30}$ & \multicolumn{2}{|c|}{$\begin{array}{l}\quad n=8 \\
G=\text { no existent }\end{array}$} & $\begin{array}{l}\text { quasi-experimental } \\
\text { study }\end{array}$ & $\mathrm{PG}=2 \mathrm{x} /$ week during 8 weeks -- apparatus and on mat \\
\hline Markovic et al. ${ }^{25}$ & \multicolumn{2}{|c|}{$\begin{array}{rl}\mathrm{n}=34 & 70 \pm 4 \\
\mathrm{PG} & =17 \\
\mathrm{HG} & =17\end{array}$} & $\begin{array}{l}\text { randomized controlled } \\
\text { trial }\end{array}$ & $\begin{array}{c}\mathrm{PG}=3 \mathrm{x} / \text { week during } 8 \text { weeks -- elastic band } \\
\mathrm{HG}=3 \mathrm{x} / \text { week during } 8 \text { weeks -- training performed on Huber device }\end{array}$ \\
\hline Mesquita et al. ${ }^{27}$ & $\begin{array}{l}\mathrm{PG}=21 \\
\mathrm{CG}=21 \\
\mathrm{PNFG}=2\end{array}$ & $\begin{array}{l}63 \\
\quad \begin{array}{r}67.3 \pm 4.9 \\
71.5 \pm 6.2 \\
68.5 \pm 5.4\end{array}\end{array}$ & $\begin{array}{l}\text { randomized controlled } \\
\text { trial }\end{array}$ & $\begin{array}{c}\text { PG }=3 \mathrm{x} / \text { week during } 4 \text { weeks -- on the ground } \\
\mathrm{CG}=\text { continued their daily activities } \\
\text { PNFG }=3 \mathrm{x} / \text { week during } 4 \text { weeks resistance, manual pressure, traction, } \\
\text { stretch-approximation reflexes and visual and verbal stimulation }\end{array}$ \\
\hline Mokhtari et al. ${ }^{31}$ & \multicolumn{2}{|c|}{$\begin{array}{c}P G=15 \\
C G=15\end{array}$} & $\begin{array}{l}\text { quasi-experimental } \\
\text { study }\end{array}$ & $\begin{array}{c}\mathrm{PG}=3 \mathrm{x} / \text { week during } 12 \text { weeks -- on mat and with elastic } \\
\mathrm{CG}=\text { maintained normal physical activity }\end{array}$ \\
\hline Newel et al. ${ }^{32}$ & $\begin{array}{l}\mathrm{PG}=9 \\
\mathrm{CG}=\end{array}$ & $\begin{array}{l}=9 \\
\quad 67.8 \pm 5 \\
\text { lo existent }\end{array}$ & $\begin{array}{l}\text { quasi-experimental } \\
\text { study }\end{array}$ & $P G=1 x$ /week during 8 weeks -- on mat \\
\hline Pata et al. ${ }^{33}$ & \multicolumn{2}{|c|}{$\begin{array}{c}\mathrm{PG}=35 \\
\mathrm{CG}=\text { no existent }\end{array}$} & $\begin{array}{l}\text { quasi-experimental } \\
\text { study }\end{array}$ & $P G=2 x /$ week during 8 weeks --on mat, elastic and apparatus \\
\hline Sofianidis et al. ${ }^{29}$ & $\begin{array}{l}\mathrm{PG}=12 \\
\mathrm{DG}=12 \\
\mathrm{CG}=12\end{array}$ & $\begin{array}{l}=36 \\
70.76 \pm 5.42 \\
70.59 \pm 5.78 \\
70.37 \pm 5.97\end{array}$ & $\begin{array}{l}\text { randomized controlled } \\
\text { trial }\end{array}$ & $\begin{array}{c}\text { PG }=2 \mathrm{x} / \text { week during } 12 \text { weeks with power balls, ribbons-tires and } \\
\text { weights } \\
\begin{array}{c}\text { DG }=2 \mathrm{x} / \text { week during } 12 \text { weeks latin dances with and without a } \\
\text { partner } \\
\text { CG }=\text { instructed not to do any form of exercise }\end{array}\end{array}$ \\
\hline
\end{tabular}

PG = Pilates Group; CG: Control Group; BAL = Balance Training Group; TG = Traditional Group; HG = Huber group; PNFG = Proprioceptive Neuromuscular Facilitation Group; DG = dancing group.

per week between 8 to 12 weeks allow improvements in balance and may prevent falls. Bird et al. ${ }^{34}$ suggest that after the fifth week it is already possible to identify balance improvement. Mesquita et al. ${ }^{27}$ found that when 
Table 3 - Balance variables and outcomes description of included articles.

\begin{tabular}{|c|c|c|}
\hline Study & Balance variables studied & Key results pos-training \\
\hline Barker et al. ${ }^{22}$ & $\begin{array}{c}\text { Step test; functional } \\
\text { reach test; lateral reach test; TUG; modified clinical } \\
\text { test of sensory interaction on balance; dynamic gait } \\
\text { index; FSST }\end{array}$ & Standing balance in the Pilates group \\
\hline Bird et al. ${ }^{34}$ & $\begin{array}{c}\text { Static balance (FP) } \\
\text { Dynamic balance (FSST, TUG) }\end{array}$ & FSST, TUG / body sway in medial-lateral direction \\
\hline Siqueira et al. ${ }^{20}$ & Dynamic Balance (Tinetti) & Balance \\
\hline Donath et al. ${ }^{23}$ & $\begin{array}{c}\text { single limb stance }{ }^{40} \text { and perturbed kneeling, YBalance } \\
\text { test }\end{array}$ & $\begin{array}{l}\text { Static and dynamic balance in the BAL group } \\
\text { Unclear effect of balance in the Pilates group }\end{array}$ \\
\hline Gabizon et al. ${ }^{24}$ & $\begin{array}{c}\text { Static balance (FP) } \\
\text { Dynamic balance (Berg balance score) }\end{array}$ & No difference between groups. No improvement in groups \\
\hline Hyun et al. ${ }^{21}$ & $\begin{array}{c}\text { Static balance (FP) } \\
\text { Dynamic balance (TUG) }\end{array}$ & $\begin{array}{l}\text { Static and Dynamic Balance in both groups. Pilates group showed } \\
\text { better static balance when compared to the control group in the post test }\end{array}$ \\
\hline Irez et al. ${ }^{19}$ & Static Balance (FP) & Balance of Pilates group \\
\hline Josephs et al. ${ }^{28}$ & Dynamic balance TUG FAB; ABC. & $\begin{array}{l}\text { FAB in both groups } \\
\mathrm{ABC} \text { in Pilates group }\end{array}$ \\
\hline Kaesler et al. ${ }^{30}$ & $\begin{array}{c}\text { Dynamic Balance (sway meter and maximal balance } \\
\text { range test) }\end{array}$ & Sway meter with closed eyes and TGUGT of Pilates group \\
\hline Markovic et al. ${ }^{25}$ & Static balance (FP) & $\begin{array}{l}\text { Training with Huber device was more effective to the balance than } \\
\text { Pilates training }\end{array}$ \\
\hline Mesquita et al. ${ }^{27}$ & $\begin{array}{c}\text { Stabilometry }(\mathrm{FB}) \\
\text { Dynamic balance TUG, Functional reach test, Berg } \\
\text { balance score }\end{array}$ & $\begin{array}{l}\text { Static balance in proprioceptive neuromuscular group } \\
\text { Dynamic balance in both training group }\end{array}$ \\
\hline Mokhtari et al. ${ }^{31}$ & $\begin{array}{l}\text { Dynamic Balance (maximal balance range test and } \\
\text { TUG) }\end{array}$ & Balance (maximal balance range test and TUG) of Pilates group \\
\hline Newel et al. ${ }^{32}$ & Static Balance ${ }^{40}$ & balance $(\mathrm{p}>0.05)$ \\
\hline Pata et al. ${ }^{33}$ & $\begin{array}{l}\text { Dynamic balance (maximal balance range test, TUG } \\
\text { and turn } 180^{\circ} \text { test) }\end{array}$ & $\begin{array}{l}\text { TUG and turn } 180^{\circ} \text { test } \\
\text { Balance }(p>0.05)\end{array}$ \\
\hline Sofianidis et al. ${ }^{29}$ & $\begin{array}{l}\text { Tandem stance, one leg stance and periodic sway with } \\
\text { and without metronome guidance }\end{array}$ & $\begin{array}{c}\text { Both intervention's groups } \\
\text { Trunk sway amplitude (Tandem stance - eyes closed) } \\
\text { CoP displacement (one-leg stance)/ amplitude of trunk oscillation (sway } \\
\text { task) }\end{array}$ \\
\hline
\end{tabular}

$\mathrm{FP}=$ Force Plataform. FSST $=$ four square step test. $\mathrm{TUG}=$ time up and go. FAB $=$ Fullerton Advanced Balance Scale. ABC $=$ Activities-Specific Balance Confidence Scale.

Pilates is practiced with a higher weekly frequency, i.e. three times a week, 12 sessions were sufficient to promote changes in balance. Hyun et al. ${ }^{21}$ and Mokhtari et al. ${ }^{31}$ also found balance improvement after 12 weeks of Pilates practice three times per week. Curiously, Gabizon et al. ${ }^{24}$ did not find improvement on balance with Pilates intervention three times a week in 36 sessions. Maybe the exercises performed were not balance challenging enough for the population studied. In addition, Markovic et al..$^{25}$ observed that practice with Huber device can be more effective to training balance than Pilates.

Different methods of practicing Pilates showed positive results. For example, practice using elastic or springs as resistance has shown to provide greater positive effect on increasing force ${ }^{19}$. On the other hand, mat exercises can be performed in any place with a lower cost. Other interventions analyzed also showed improvement similar or greater in balance, i.e., traditional balance ${ }^{23}$ and strength training ${ }^{28}$, proprioceptive neuromuscular facilitation $^{27}$, training performed on Huber device ${ }^{25}$ and latin dances ${ }^{29}$. Regardless the type of exercises, the frequency of session must be considered, once exercise with apparatus or combined exercises (apparatus and mat) had shown no effect at a lower frequency (once a week for example). These results can be justified by the fact that with a lower frequency participants were not able to adapt and retain the benefits that Pilates exercise may cause.

Although these studies did not assess the mechanisms responsible for the effect of Pilates training, Pata et al. ${ }^{33}$ suggest that the increase in balance can be a con- 
sequence of the strengthening of core muscle which allows for greater distal mobility and a better control of body alignment. This idea is supported by Kibler ${ }^{35}$ who claim that the correct activation of the core enable an anticipatory postural adjustments which creates a stable base of support for performing activities. While Mokhtari et al. ${ }^{31}$ state that muscle activation and proprioceptive stimulus performed during intervention may cause a displacement of the center of the ankle joint, thus improving balance. Similarly, Siqueira et al. ${ }^{20}$ claim that increases in strength might improve the speed of muscle activation response and proprioception. As a consequence, it is possible to verify an improvement in balance and autonomy of the participants.

Considering that the average age of the population of the related studies is above 65 years, minor imbalance is important so that individuals can perform activities of daily life more easily, reducing the risk of falling and increasing independency in performing the movements. Other benefits related to the practice of Pilates, which are important for the health of the elderly, are improvements in functionality ${ }^{20,30}$, velocity and step length ${ }^{32}$. Thus, the practice of Pilates is recommended for preserving functional abilities that change with aging. Despite the moderate to good score for methodological quality and strength of the scientific evidence, this literature review has the limitation that none of the articles evaluated the mechanism responsible for the effect of practicing Pilates on balance. Thus, only speculations can be used to explain the changes between the variables tested.

Articles demonstrated moderate methodological quality and science evidence. Pilates training demonstrated in general positive results on balance, functionality, gait speed and stride length of elderly. Core muscle strengthening, activation of proprioception, improvement in strength and speed of muscle activation response, might be possible explanations for the benefits founded. Improving balance is important for maintaining a better ability to perform activities of daily life, decrease the risk of falling and increase independence in performing simple and complex movements ${ }^{5,6}$.

Current literature suggests that Pilates training should be performed at least twice per week in sessions with apparatus or a combination of mat and apparatus exercise and three times per week on mat only to balance improvements. The duration of the session must be at least of 40 minutes, for a period equal or greater than five weeks when practiced twice per week or from 12 sessions, when practiced three times per week with challenge and task specific, in order to be significantly effective in improving balance of the elderly.

\section{Conflict of Interest}

The authors declare no conflict of interest

\section{Authors' Contribution}

Goedert A, conceptualized the study, conducted the initial search and wrote the first draft of the manuscript. Santos KB, supplied the acquisition of data, analysis and interpretation. Bento PCB, was responsible for the article critically for important intellectual content. Rodacki ALF, provided the revised the article critically for important intellectual content and gave final approval of the version to be submitted.

\section{Reference}

1. Franco PG, Santos KB, Rodacki AL. Joint positioning sense, perceived force level and two-point discrimination tests of young and active elderly adults. Braz J Phys Ther. 2015;19(4):304-10.

2. Bento PCB, Rodacki ALF, Homann D, Leite N. Exercícios físicos e redução de quedas em idosos: uma revisão sistemática. Rev Bras Cineantropom Desempenho Hum. 2010;12(6):471-9.

3. Knudson D. Fundamentals of biomechanics.: Springer Science \& Business Media; 2007.

4. Hrysomallis C. Balance ability and athletic performance. Sports Med. 2011;41(3):221-32.

5. Winter DA, Patla AE, Frank JS. Assessment of balance control in humans. Med Prog Techno. 1990;16(1-2):31-51.

6. Horak FB. Postural orientation and equilibrium: what do we need to know about neural control of balance to prevent falls? Age Ageing. 2006;35(suppl 2):ii7-ii11.

7. Horak FB, Macpherson JM. Postural orientation and equilibrium. Compr Physiol. 1996.

8. Iqbal K. Mechanisms and models of postural stability and control. Engineering in Medicine and Biology Society, EMBC, 2011 Annual International Conference of the IEEE; Boston, MA, USA. 2011.

9. Barela JA.Estratégias de controle em movimentos complexos: ciclo percepção-ação no controle postural. Rev Paul Educ Fís. 2000;1(Suppl 3):79-88.

10. Muscolino JE, Cipriani S. Pilates and the "powerhouse"-I.J Bodyw Mov Ther. 2004;8(1):15-24.

11. Kloubec J. Pilates: how does it work and who needs it? Muscles, Ligaments Tendons J. 2011;1(2):61.

12. Marés G, Oliveira KB, Piazza MC, Preis C, Bertassoni Neto L. A importância da estabilização central no método Pilates: uma revisão sistemática; The importance of central stabilization in Pilates method: a systematic review. Fisioter Mov. 2012;25(2):445-51.

13. Hodges PW, Richardson CA. Transversus abdominis and the superficial abdominal muscles are controlled independently in a postural task. Neurosci Lett. 1999;265(2):91-4.

14. Fredericson M, Moore T. Core stabilization training for middle and long distance runners. New Stud Athlet. 2005;20(1):25-37. 
15. Iulian-Doru T, Vasilica G, Mariaa T, Claudia-Cameliaa B. Pilates Principles-Psychological Resources for Efficiency Increase of Fitness Programs for Adults. Procedia Soc Behav Sci. 2013;84:658-62.

16. Latey P. The Pilates method: history and philosophy.J Bodyw Mov Ther. 2001;5(4):275-82.

17. Cruz-Ferreira A, Fernandes J, Laranjo L, Bernardo LM, Silva A. A systematic review of the effects of pilates method of exercise in healthy people. Arch Phys Med Rehabil. 2011;92(12):2071-81.

18. Chodzko-Zajko WJ, Proctor DN, Singh MAF, Minson CT, Nigg CR, Salem GJ, et al. Exercise and physical activity for older adults. Med Sci Sports Exerc. 2009;41(7):1510-30.

19. Irez GB, Ozdemir RA, Evin R, Irez SG, Korkusuz F. Integrating Pilates exercise into an exercise program for $65+$ year-old women to reduce falls. J Sports Sci Med. 2011;10:105-11.

20. Rodrigues BGS, Cader SA, Torres NVOB, Oliveira EM, Dantas EHM. Pilates method in personal autonomy, static balance and quality of life of elderly females. J Bodyw Mov Ther. 2010;14(2):195-02.

21. Hyun J, Hwangbo K, Lee CW. The effects of Pilates mat exercise on the balance ability of elderly females. J Phys Ther Sci. 2014;26(2):291.

22. Barker AL, Talevski J, Bohensky MA, Brand CA, Cameron PA, Morello RT. Feasibility of Pilates exercise to decrease falls risk: a pilot randomized controlled trial in communitydwelling older people. Clin Rehabil. 2016;30(10):984-96.

23. Donath L, Roth R, Hürlimann C, Zahner L, Faude O. Pilates vs. balance training in health community-dwelling seniors: a 3-arm, randomized controlled trial. Int J Sports Med. 2016;37(03):202-10.

24. Gabizon H, Press Y, Volkov I, Melzer I. The Effects of Pilates Training on Balance Control and Self-Reported Health Status in Community-Dwelling Older Adults: A Randomized Controlled Trial. J Aging Phys Act. 2016;24(3):376-83.

25. Markovic G, Sarabon N, Greblo Z, Krizanic V. Effects of feedback-based balance and core resistance training vs. Pilates training on balance and muscle function in older women: A randomized-controlled trial. Arch Gerontol Geriatr. 2015;61(2):117-23.
26. Yanai T, Hay JG, Gerot JT. Three-dimensional videography of swimming with panning periscopes. J Biomech. 1996;29(5):673-8.

27. Mesquita LS, Carvalho FT, Freire LS, Pinto Neto O, Zângaro RA. Effects of two exercise protocols on postural balance of elderly women: a randomized controlled trial. BMC Geriatr. 2015;15(1):61.

28. Josephs S, Pratt ML, Meadows EC, Thurmond S, Wagner A. The effectiveness of Pilates on balance and falls in community dwelling older adults. J Bodyw Mov Ther. 2016;20(4):815-23.

29. Sofianidis G, Dimitriou A, Hatzitaki V. A comparative study of the effects of pilates \& Latin dance on static and dynamic balance in older adults. J Aging Phys Act. 2016:1-26.

30. Kaesler D, Mellifont R, Kelly PS, Taaffe D. A novel balance exercise program for postural stability in older adults: A pilot study. J Bodyw Mov Ther. 2007;11(1):37-43.

31. Mokhtari M, Nezakatalhossaini M, Esfarjani F. The Effect of 12-Week Pilates Exercises on Depression and Balance Associated with Falling in the Elderly. Procedia Soc Behav Sci. 2013;70:1714-23.

32. Newell D, Shead V, Sloane L. Changes in gait and balance parameters in elderly subjects attending an 8-week supervised Pilates programme. J Bodyw Mov Ther. 2012;16(4):549-54.

33. Pata RW, Lord K, Lamb J. The effect of Pilates based exercise on mobility, postural stability, and balance in order to decrease fall risk in older adults. J Bodyw Mov Ther. 2014;18(3):361-7.

34. Bird ML, Hill KD, Fell JW. A randomized controlled study investigating static and dynamic balance in older adults after training with Pilates. Arch Phys Med Rehabil. 2012;93(1):43-9.

35. Kibler WB, Press J, Sciascia A. The role of core stability in athletic function. Sports Med. 2006;36(3):189-98.

Recebido: 29/11/2017

Aprovado: 07/08/2018

Quote this article as:

Goedert A, Santos KB, Bento PCB, Rodacki ALF. The effect of pilates practice on balance in elderly: a systematic revierw. Rev Bras Ati Fis Saúde. 2018;23:e0019. DOI: 10.12820/rbafs.23e0019 